\title{
Sprawozdanie z konferencji naukowej: „Kształcenie ustawiczne dla potrzeb rynku pracy"- Poznań 27 listopad 2013 r.
}

W dniu 27.XI.2013 roku odbyła się w Poznaniu konferencja I Poznańskie Forum Dyskusyjne LLL, która zapoczątkowała cykl spotkań tematycznych z zakresu całożyciowego uczenia się. W odpowiedzi na dynamiczne zmiany zachodzące w otaczającej nas rzeczywistości, w tym trudny rynek pracy oraz edukacyjny kontekst tych zmian, tematem pierwszego spotkania organizatorzy konferencji uczynili „Kształcenie ustawiczne dla potrzeb rynku pracy”. Konferencja zorganizowana została przez Zakład Kształcenia Ustawicznego i Doradztwa Zawodowego na Wydziale Studiów Edukacyjnych Uniwersytetu im. Adama Mickiewicza w Poznaniu.

Podstawowym celem konferencji było zaprezentowanie głównych kierunków zmian w obszarze szeroko pojętego rynku pracy oraz stworzenie optymalnych warunków do dyskusji o najistotniejszych problemach z zakresu aktywności zawodowo-edukacyjnej osób dorosłych.

$\mathrm{Na}$ zaproszenie organizatorów odpowiedzieli przedstawiciele nauki $\mathrm{z}$ wiodących ośrodków akademickich w Polsce, zajmujący się problematyką całożyciowego uczenia się.

Obrady rozpoczęło uroczyste powitanie gości przez Przewodniczącą Komitetu Naukowego prof. zw. dr hab. Ewę Solarczyk-Ambrozik - kierownika Zakładu Kształcenia Ustawicznego i Doradztwa Zawodowego na Wydziale Studiów Edukacyjnych UAM.

Debata konferencyjna podzielona była na 3 części, część pierwszą i drugą stanowiły wystąpienia plenarne zaproszonych ekspertów wraz z dyskusją, a część trzecią sesja posterowa. 
Podczas pierwszej sesji zaprezentowane zostały trzy wystąpienia. Tę część spotkania moderowała dr Anna Wawrzonek.

Jako pierwsza referat wygłosiła prof. Ewa Solarczyk-Ambrozik. Prelegentka zaprezentowała temat „Orientacja na rynek pracy w strategiach całożyciowego uczenia się". W trakcie wystąpienia analizie poddano wiodące dokumenty unijne, podejmujące tematykę LLL. Wystąpienie ukierunkowane było na wskazanie istoty powiązań kształcenia ustawicznego z rynkiem pracy oraz wyłonienie niezwykle ważnych problemów i wyzwań kształcenia ustawicznego, które stanowiły podbudowę późniejszej dyskusji. Prof. E. Solarczyk-Ambrozik odwoływała się między innymi do takich kwestii jak: ramy kwalifikacyjne i ich znaczenie dla strategii całożyciowego uczenia się, mobilność pracownicza, problem podaży edukacyjnej oraz dostępności do zróżnicowanej oferty edukacyjnej.

Kolejny referat został wygłoszony przez prof. zw. dr hab. Zbyszko Melosika, dziekana Wydziału Studiów Edukacyjnych, Uniwersytetu im. Adama Mickiewicza. Referat prof. Melosika dotyczył zagadnień skoncentrowanych wokół tematu „Tożsamość młodzieży, neoliberalizm i rynek pracy”. Prelegent dokonał wnikliwej analizy i charakterystyki młodego pokolenia na współczesnym rynku pracy. Wskazał dążenia i wartości kształtujące tożsamość edukacyjno-zawodową młodzieży żyjącej w czasach, kiedy kształcenie ustawiczne staje się czymś na kształt obsesji, a niestabilność oraz permanentna rynkowa readaptacja powszechnie akceptowaną normą. Prof. Melosik wielokrotnie wskazywał na neurotyczną wręcz potrzebę młodych osób, rozpoczynających karierę zawodową do osiągania perfekcji, dyktowaną koniecznością dostosowywania się do coraz to nowszych wymagań współczesnego, neoliberalnego rynku pracy i świata.

Jako ostatni podczas pierwszej sesji wystąpił prof. zw. dr hab. Stefan Kwiatkowski z Akademii Pedagogiki Specjalnej im. Marii Grzegorzewskiej w Warszawie. Temat referatu brzmiał „Walidacja efektów kształcenia pozaformalnego i nieformalnego". Przedmiotem wystąpienia prof. Kwiatkowskiego były refleksje dotyczące wieloletnich doświadczeń badawczych prelegenta nad ramami kwalifikacji, standardami kompetencji zawodowych i kwalifikacji zawodowych. Kluczową część wystąpienia stanowiły rozważania na temat walidacji kompetencji jako procesu potwierdzania kompetencji. Referent podkreślał, iż współcześnie mamy do czynienia z implementowaniem nowej filozofii dochodzenia do zawodu, co stawia szereg wyzwań przed szeroko pojętą edukacją dorosłych. W wystąpieniu zaproponowane zostały także pytania dotyczące sposobu funkcjonowania instytucji walidujących kompetencje oraz tego jakie instytucje powinny się tym zajmo- 
wać i kto powinien je powoływać, a także pytania dotyczące relacji pomiędzy procesem walidacji efektów kształcenia a rolą szkół wyższych w tym zakresie. W wystąpieniu podjęte zostały także wątki dotyczące kategoryzacji wiedzy i kompetencji.

Problemy zasygnalizowane przez prelegentów podczas pierwszej sesji stanowiły inspirację do dyskusji. Głos w dyskusji zabrali prof. K. Przyszczypkowski, prof. S. Kwiatkowski, prof. T. Aleksander, prof. E. Kurantowicz, prof. E. Solarczyk-Ambrozik oraz dr A. Jurgiel-Aleksander. Dyskusja koncentrowała się wokół tematów zaproponowanych przez referentów, w szczególności wokół problemu walidacji efektów kształcenia. Istotnym problemem podjętym w trakcie dyskusji było również krytyczne podejście do zawężania edukacji do perspektywy rynku pracy. W trakcie debaty pojawiały się także pytania dotyczące zasadności standardów kwalifikacyjnych. W rezultacie dyskusji wskazano dwa koegzystujące ze sobą porządki w dyskursie dotyczącym myślenia o kompetencjach, a mianowicie: język administrowania kompetencjami oraz dyskurs koncentrujący się na poszukiwaniu sensu i znaczenia współczesnej edukacji. W podsumowaniu dyskusji prof. E. Solarczyk-Ambrozik wskazała, iż proces walidacji zmienia oblicze systemu edukacyjnego oraz funkcję uniwersytetów.

$\mathrm{Na}$ drugą część spotkania zaplanowane zostały cztery wystąpienia, których celem było nie tylko zaprezentowanie wybranych zagadnień, ale także zaproszenie do dalszej dyskusji nad relacją pomiędzy kształceniem ustawicznym a rynkiem pracy. Tę część spotkania moderowała dr Małgorzata Rosalska.

Jako pierwszy wystąpił prof. zw. dr hab. Kazimierz Przyszczypkowski z Uniwersytetu im. Adama Mickiewicza w Poznaniu. Referent zaprezentował temat „Humanistyka w perspektywie rynku pracy”. Było to wystąpienie w krytyczny sposób ukazujące pozycję humanistyki i humanistów w kontekście wyzwań i wymagań rynku pracy. Profesor K. Przyszczypkowski wskazał na brak dyskursu dotyczącego wartości w dyskusjach nad rynkiem pracy, odniósł się także do dominującego w pracach ekspertów, teoretyków i praktyków myślenia w kategoriach neoliberalizmu. W wystąpieniu podjęte zostały również wątki dotyczące edukacji dla rynku pracy i doradztwa zawodowego. W tym kontekście sformułowane zostały ważne pytania, jak i do jakiego rynku pracy przygotowywać uczniów w systemie edukacyjnym. Pytanie o miejsce humanistyki w perspektywie rynku pracy generują kolejne pytania: czy człowiek ma być elementem rynku pracy, czy rynek pracy może być miejscem realizacji wartości humanistycznych, ogólnoludzkich, sprzyjających rozwojowi człowieka postrzeganego całościowo, 
a nie tylko poprzez pryzmat jego przydatności do efektywnego wykonywania zadań zawodowych.

Kolejny referat zaprezentowany przez prof. zw. dr hab. Zdzisława Wołka z Uniwersytetu Zielonogórskiego dotyczył „Edukacji w strategiach życiowych osób długotrwale bezrobotnych". Prelegent zaproponował kilka perspektyw analizowania roli edukacji w indywidualnych strategiach wychodzenia z sytuacji bezrobocia. W wystąpieniu scharakteryzowana została sytuacja osób długotrwale bezrobotnych. Profesor Z. Wołk odnosząc się do koncepcji teoretycznych i badań, podzielił się refleksjami na temat edukacyjnych mechanizmów przeciwdziałania skutkom długotrwałego bezrobocia oraz wybranych strategii pomocy osobom doświadczającym syndromu wyuczonej bezradności. Ta perspektywa oglądu związków między edukacją a rynkiem pracy wskazała na kolejny aspekt analizy tych relacji, pojawiło się pytanie o zależności między edukacją a pracą socjalną i innymi mechanizmami przeciwdziałającymi marginalizacji i wykluczeniu społecznemu.

Trzeci referent - prof. UWK dr hab. Ryszard Gerlach zaproponował temat „Rynek pracy wyzwaniem dla pozaszkolnej edukacji zawodowej”. To wystąpienie ukierunkowane było na wskazanie nowych zadań i wyzwań, które stoją przed pozaszkolną edukacją zawodową w kontekście nie tylko przemian rynku pracy, ale także reformy kształcenia w zawodach. Profesor R. Gerlach ukazał to zagadnienie w perspektywie pedagogiki pracy. Odnosząc się do charakterystyki współczesnego rynku pracy, do jego dynamiki i uwarunkowań rozwoju wskazał, że zmiany w obszarze pozaszkolnej edukacji są konieczne i że ta forma edukacji zawodowej będzie zyskiwać na znaczeniu. Ten proces będzie wymuszał także zmiany w procesie kształcenia, coraz wyraźniej będą formułowane pytania o kompetencje nauczycieli edukacji pozaszkolnej oraz o formy i strategie uznawania kwalifikacji zawodowych uzyskiwanych poza szkolnymi, tradycyjnymi formami kształcenia w zawodach.

Ostatni referat został zaprezentowany przez prof. UAM dr. hab. Sławomira Banaszaka. Temat „Nowoczesny rynek pracy: stałość, zmienność czy zróżnicowanie?” był wyraźnym zaproszeniem do dyskusji. Prelegent wskazał na kluczowe teoretyczne koncepcje analizowania procesów zachodzących na rynku pracy. W wystąpieniu zaproponowane zostały pytania dotyczące relacji pomiędzy zmianami na rynku pracy oraz przeobrażeniami w zakresie wykonywania pracy a zmianami w edukacji. Prof. Banaszak wskazał, że w świetle badań praca zaczyna być postrzegana przez młode pokolenie inaczej niż przez ich rodziców. Postrzeganie roli i znaczenia pracy jest coraz bardziej różnicowane przez płeć, inne plany i role życiowe, konteksty społeczne i kulturowe. Te zmiany, według prelegenta, powinny mieć także 
odzwierciedlenie w procesach edukacyjnych, szczególnie w obszarze kształtowania proaktywnych postaw wobec własnej kariery zawodowej.

Po tych wielowątkowych wystąpieniach moderator sesji zaprosiła uczestników do dyskusji. Głos zabrali prof. T. Aleksander, prof. Z. Wołk, prof. S. Kwiatkowki, prof. K. Przyszczypkowski, prof. R. Gerlach, prof. E. Dubas, prof. S. Banaszak. Dyskusja koncentrowała się wokół tematów zaproponowanych przez referentów. Mocno dyskutowany był wątek dotyczący relacji między rynkiem pracy a wartościami humanistycznymi oraz rolą kształcenia ustawicznego we wspieraniu całościowo ujmowanego rozwoju człowieka. Ciekawym wątkiem była także analiza relacji pomiędzy zmianami wynikającymi z procesu implementacji założeń krajowych ram kwalifikacji do obszaru kształcenia dorosłych i kształcenia zawodowego. Uczestnicy dyskusji wskazali na potrzebę uwzględniania sfery wartości w projektowaniu oddziaływań edukacyjnych. Skoncentrowanie się wyłącznie na rynku pracy i kompetencjach warunkujących sukces zawodowy obarczone jest niebezpieczeństwem bardzo zredukowanego postrzegania edukacji w procesie wspierania rozwoju człowieka w ciągu całego życia.

Trzecią część konferencji stanowiła sesja posterowa, w trakcie której uczestnicy konferencji mogli zapoznać się z różnorodnymi zagadnieniami zaprezentowanymi, wpisującymi się $\mathrm{w}$ tematykę konferencji, w formie plakatów. Podczas sesji posterowej zaprezentowano 14 następujących plakatów: dr Magdalena Barańska „Rola uczelni wyższych w przygotowaniu studentów i absolwentów do wchodzenia na rynek pracy", dr Monika Bartkowiak „Współczesny pracodawca w obliczu wymagań rynku pracy”, dr Michał Klichowski „Cyborgizacja i kres kształcenia”, dr Renata Konieczna-Woźniak „Między stabilnością a elastycznością - trudna sytuacja osób starszych na rynku pracy”, dr Mariusz Przybyła „Uczenie się w rzeczywistości rozszerzonej vs nowe przestrzenie edukacji - cyborgizacja", dr Małgorzata Rosalska „Kluczowe cele doradztwa zawodowego w systemie edukacyjnym”, dr Joanna Szłapińska „Studia podyplomowe MBA jako forma kształcenia ustawicznego", dr Anna Wawrzonek „Czy pracownik „Hlexi” znaczy gorszy czy lepszy?”, mgr Elwira Litaszewska i mgr Sylwia Polcyn „Rozwój kompetencji nauczyciela za pomocą wirtualnych środków dydaktycznych”, mgr Kinga Majchrzak „Wykorzystanie potencjału edukacyjnego miejsc pamięci UMK w procesie kształcenia studentów”, mgr Anna Matusiak „Rozwój w obszarze kompetencji społecznych studentów z wykorzystaniem metody portfolio uczenia się”, mgr Agata Szwech „Uczenie się na podstawie biografii Innego - analiza dzienników osobistych”, mgr Jakub Wierzbicki „Profilowanie bezrobotnych - wyzwanie dla kształcenia doradców zawodowych”, 
lic. Małgorzata Kasprzak „Życie jak w Madrycie? Czyli młodzi bezrobotni na hiszpańskim rynku pracy". Zagadnienia zaprezentowane na posterach stanowiły tło rozważań podjętych w trakcie dyskusji wieńczącej konferencję.

I Poznańskie Forum Dyskusyjne LLL okazało się inicjatywą potrzebną i konstruktywną. Zaproponowana formuła spotkania stwarza możliwości do dyskusji, przedstawienia własnych ustaleń badawczych, przemyśleń i sposobów interpretowania edukacyjnej rzeczywistości. Forum jest także szansą na zaprezentowanie w środowisku osób zajmujących się szeroko rozumianą edukacją dorosłych, aktualnych zamierzeń badawczych i namysłu nad kluczowymi wyzwaniami stojącymi przed naszą dyscypliną. To także szansa na integrowanie środowiska osób zaangażowanych $\mathrm{w}$ tę tematykę. Szczególne znaczenie ma to dla młodszych badaczy. Spotkania z ekspertami, możliwość uczestniczenia w dyskusji, zaprezentowania efektów własnej pracy podczas sesji posterowej pozwala skonfrontować, przedyskutować własny warsztat i ścieżki interpretacyjne z pracami innych osób. W opinii organizatorów i wielu uczestników zaletą tej konwencji spotkania jest przede wszystkim czas na dyskusję, która podczas tego Forum była bardzo inspirująca. Ta formuła pracy będzie kontynuowana podczas kolejnych spotkań w ramach Poznańskiego Forum Dyskusyjnego LLL. Tematem drugiego spotkania organizatorzy pragną uczynić „Doradztwo zawodowe w perspektywie całożyciowego uczenia się".

Anna Wawrzonek, Małgorzata Rosalska 